\title{
Persepsi Pembudidaya Ikan Terhadap Kompetensi Penyuluh Perikanan di Kawasan Minapolitan (Kasus di Kabupaten Cirebon, Provinsi Jawa Barat)
}

\section{The Perception of Fish Farmers Towards Competence of Fisheries Extension Workers in Minapolitan Region. Case in Cirebon Regency, West Java Province}

\author{
Ikhsan Haryadi $^{1}$, Siti Amanah ${ }^{1}$, Sumardi Suriatna ${ }^{2}$ \\ ${ }^{1}$ Departemen Sains Komunikasi dan Pengembangan Masyarakat, \\ akultas Ekologi Manusia, Institut Pertanian Bogor, Bogor \\ ${ }^{2}$ Komisi Penyuluhan Perikanan Nasional (KPPN)
}

\begin{abstract}
Research objectives were: 1) to describe the profile fish farmers, 2) to analyze the perception of fish farmers towards competence of fisheries extension worker, and 3 ) to analyze the relationship between the profile of fish farmers and fisheries extension services towards of fish farmers perceptions of competence of fisheries extension workers. The study was conducted in Cirebon regency, West Java Province. The sample was 100 respondents of fish farmers is determined by the formula Slovin. Processing and analysis of data using descriptive statistics and inferential statistics (Rank Spearmen). The results showed profiles of fish farmers mostly adult age category (39-57 years). Majority of low educational level or not complete primary school or complete primary school. Participation in fisheries training and experience of fishing bussines is low. Perceptions of fish farmer towards competence of fisheries extension worker is the medium category, except towards personal competence is high category with details of the personal competence is $64 \%$, andragogik competence is $61 \%$, professional competence is $59 \%$ and social competence is 60\% The better the extension given material, the better the fisheries extension perceptions fish farmers to professional and social competence fisheries extension workers. The better implementation methods and techniques of extension, the better the perception of fish farmers towards personal competence, social and professional of fisheries extension workers.
\end{abstract}

Keywords : fish farmers's perception, competence of fisheries extension worker, minapolitan region

\begin{abstract}
Abstrak
Penelitian ini bertujuan untuk: 1) mendeskripsikan profil pembudidaya ikan, 2) menganalisis persepsi pembudidaya ikan terhadap kompetensi penyuluh perikanan, dan 3) menganalisis hubungan antara profil pembudidaya ikan dengan persepsi pembudidaya ikan terhadap kompetensi penyuluh perikanan. Lokasi penelitian di Kabupaten Cirebon Provinsi Jawa Barat. Sampel penelitian adalah 100 responden pembudidaya ikan ditentukan dengan rumus Slovin. Hasil penelitian menunjukkan profil pembudidaya ikan sebagian besar kategori usia dewasa (39-57 tahun). Tingkat pendidikan mayoritas rendah atau tidak tamat SD atau tamat SD. Keikutsertaan dalam pelatihan dan pengalaman usaha termasuk kategori rendah. Persepsi pembudidaya ikan terhadap kompetensi penyuluh perikanan di kawasan minapolitan Kabupaten Cirebon termasuk dalam kategori sedang, kecuali terhadap kompetensi kepribadian termasuk kategori tinggi dengan rincian terhadap kompetensi kepribadian sebesar 64\%, kompetensi andragogik sebesar $61 \%$, kompetensi profesional sebesar 59\% dan kompetensi sosial $60 \%$. Semakin sering intensitas penyuluhan maka semakin baik persepsinya terhadap kompetensi andragogik penyuluh perikanan. Semakin baik materi penyuluhan yang diberikan penyuluh perikanan maka semakin baik persepsi pembudidaya ikan terhadap kompetensi profesional dan sosial penyuluh perikanan. Semakin baik metode dan teknik penyuluhan maka semakin baik persepsi pembudidaya ikan terhadap kompetensi kepribadian, profesional dan sosial penyuluh perikanan.
\end{abstract}

Kata kunci: persepsi pembudidaya ikan, kompetensi penyuluh perikanan, kawasan minapolitan

\section{Pendahuluan}

Pembangunan kelautan dan perikanan dilaksanakan dalam rangka mewujudkan empat pilar pembangunan, yaitu pro-poor (pengentasan kemiskinan), pro-job (penyerapan tenaga kerja), pro-growth (pertumbuhan), dan pro-environment (pemulihan dan pelestarian lingkungan). Salah satu program Kementerian Kelautan dan Perikanan dalam upaya peningkatan pengelolaan potensi perikanan yang terintegrasi dilaksanakan melalui Minapolitan dengan tujuan: 1). meningkatkan produksi, produktivitas, dan kualitas produk kelautan dan perikanan; 2). meningkatkan pendapatan pelaku utama perikanan (nelayan, pembudidaya ikan, dan pengolah/pemasar ikan) yang adil dan merata; dan 3). Mengembangkan kawasan minapolitan sebagai pusat pertumbuhan ekonomi di daerah (Kementerian

${ }^{1}$ Korespondensi penulis

E-mail: ikhsan_haryadi@yahoo.com 
Kelautan dan Perikanan, 2010). Pendekatan pengembangan minapolitan antara lain melalui penyuluhan perikanan (Kementerian Kelautan dan Perikanan, 2012).

Pelaksanaan Minapolitan memerlukan kehadiran penyuluh perikanan yang kompeten untuk melaksanakan peran dan tugasnya. Penyuluh perikanan yang mempunyai kompetensi tinggi akan mampu menunjukkan kinerja yang baik karena kompetensi salah satu faktor ber-pengaruh terhadap kinerja penyuluh. Hal ini sesuai dengan pendapat Spencer dan Spencer (1993) yang menyatakan bahwa kompetensi dapat memperkirakan seseorang dapat menyelesaikan pekerjaannya dengan baik atau tidak. Ditambahkan oleh Gilley dan England (1989), kompetensi merupakan kemampuan yang dimiliki seseorang sehingga yang bersangkutan dapat menyelesaikan perannya. Kompetensi penyuluh perikanan dapat diukur sudut pandang stakeholders, baik dari persepsi penyuluh perikanan itu sendiri, persepsi pembudidaya ikan sebagai pihak yang mendapat layanan penyuluhan perikanan, maupun persepsi penyuluh perikanan lain yang menjadi rekan sejawat. Litterer dalam Asngari (1984) menunjukkan bahwa persepsi orang dipengaruhi oleh pandangan seseorang pada suatu keadaan, fakta atau tindakan. Salah satu faktor dasar persepsi adalah kemampuan orang-orang mengumpulkan fakta-fakta yang terbatas dan bagian-bagian informasi kemudian menyusun dalam gambaran yang utuh.

Kabupaten Cirebon salah satu yang ditetapkan sebagai kawasan minapolitan mempunyai potensi perikanan budidaya air tawar dan payau/laut baik di wilayah barat, tengah dan timur. Dukungan pembangunan perikanan dikawasan minapolitan antara lain melalui kegiatan penyuluhan. Kelembagaan penyuluhan tingkat Kabupaten adalah Badan Ketahanan Pangan dan Pelaksana Penyuluhan Pertanian, Perikanan dan Kehutanan (BKP5K), sedangkan di kecamatan adalah Balai Penyuluhan Pertanian, Perikanan, dan Kehutanan (BP3K) dan di tingkat desa/ kawasan berupa Pos Penyuluhan. Penyuluh perikanan berjumlah 71 orang, terdiri atas 12 orang penyuluh perikanan PNS orang, 7 orang penyuluh perikanan tenaga kontrak dan 52 orang penyuluh perikanan swadaya (BKP5K Kabupaten Cirebon, 2013).

Menurut Rogers dan Shoemaker (1971), karakteristik seseorang akan ikut mempengaruhi persepsidanselanjutnyaakanmempengaruhitindakan atau perilaku. De Vito (1997) mengemukakan bahwa faktor yang mempengaruhi ketepatan persepsi diantaranya adalah umur dan kesan latihan atau hasil belajar. Faktor-faktor yang ikut mempengaruhi seleksi pada persepsi menurut Pareek (Sobur, 2003) diantaranya adalah pengalaman dan intensitas. Hasil penelitian Farida (2012) karakteristik pribadi responden yakni kesertaan dalam pelatihan usahatani menentukan persepsinya terhadap kompetensi penyuluh pertanian di Kabupaten Serang Provinsi Banten. Menurut Rusmono (2008), terdapat empat komponen kompetensi penyuluh, yakni: 1) Kompetensi kepribadian, 2) Kompetensi andragogik, 3) Kompetensi profesional dan 4) Kompetensi sosial.

Guna mengetahui kompetensi penyuluh perikanan PNS dan layanan penyuluhan perikanan di kawasan minapolitan Kabupten Cirebon, diperlukan informasi kompetensi penyuluh perikanan dilihat dari persepsi pembudidaya ikan sebagai pihak penerima manfaat penyuluhan perikanan. Masalah penelitian adalah: 1) Bagaimana profil pembudidaya ikan, 2) Bagaimana persepsi pembudidaya ikan terhadap kompetensi penyuluh perikanan dan 3) Sejauhmana hubungan antara profil pembudidaya ikan dan layanan penyuluhan perikanan dengan persepsi pembudidaya ikan terhadap kompetensi penyuluh perikanan. Tujuan penelitian adalah:

1. Mendeskripsikan profil pembudidaya ikan,

2. Menganalisis persepsi pembudidaya ikan terhadap kompetensi penyuluh perikanan, dan

3. Menganalisis hubungan antara profil pembudidaya ikan dan layanan penyuluhan perikanan dengan persepsi pembudidaya ikan terhadap kompetensi penyuluh perikanan.

\section{Metode Penelitian}

Rancangan penelitian berbentuk explanatory research, yang menurut Singarimbun dan Efendi (2008) bertujuan untuk menjelaskan hubungan kausal antara variabel-variabel melalui pengujian hipotesa. Metode yang digunakan dalam pengumpulan data adalah survei dan menggunakan paradigma kuantitatif.

Variabel bebas yang diamati dalam penelitian ini meliputi profil pembudidaya ikan (X1), yang terdiri atas umur (X1.1), tingkat pendidikan formal 
(X1.2), kesertaan dalam pelatihan perikanan (X1.3) dan pengalaman usaha perikanan (X1.4). Variabel lain yang dianggap terkait dengan tingkat persepsi pembudidaya ikan terhadap kompetensi penyuluh perikanan adalah layanan penyuluhan perikanan (X2) yakni intensitas penyuluhan perikanan (X2.1), materi penyuluhan perikanan (X2.2) dan metode dan teknik penyuluhan perikanan (X2.3). Variabel tidak bebas yaitu: persepsi pembudidaya ikan terhadap kompetensi penyuluh perikanan (Y) mencakup: kompetensi kepribadian(Y1.), kompetensi andragogik (Y2), kompetensi profesional (Y3), dan kompetensi sosial (Y4).

Lokasi penelitian disesuaikan dengan potensi perikanan meliputi wilayah barat, tengah dan timur Kabupaten Cirebon, Provinsi Jawa Barat. Populasi adalah pengurus dan anggota kelompok pembudidaya ikan yang dibina oleh penyuluh perikanan PNS. Penentuan sampel berdasarkan teknik Two Stage Cluster Sample (Scheaffer et al., 2006) diawali menggerombolkan berdasarkan wilayah potensi perikanan, kemudian dari masing-masing wilayah ditentukan kurang lebih 30\% dari total 63 kelompok didapat 18 kelompok. Sampel penelitian ditentukan dengan rumus Slovin yakni 100 pembudidaya ikan. Sampel penelitian dari 12 kecamatan yakni wilayah barat terpilih 6 kelompok di kecamatan Palimanan, Gunung Jati dan Kapetakan. Wilayah tengah terpilih 8 kelompok di kecamatan Beber, Greged, Talun, Tengahtani, Dukupuntang dan Sumber. Wilayah timur terpilih 4 kelompok di kecamatan Losari, Gebang dan Babakan.

Pengumpulan data bulan Juli-September 2013. Data primer berupa pengamatan langsung dan wawancara terstruktur. Data sekunder diperoleh dari berbagai instansi terkait. Data yang dikumpulkan dianalisis data disajikan secara deskriptif dan inferensial. Analisis deskriptif dengan membentuk tabel frekuensi dan persentase dari hasil data primer yang diperoleh berdasarkan wawancara. Analisis secara inferensial dilakukan dengan menggunakan uji statistik nonparametrik dengan menggunakan bantuan perangkat lunak program Statistical Product and Service Solutions(SPSS) 17 for Windows.

Untuk membandingkan sampel yaitu dari responden anggota kelompok pembudidaya ikan yang dibina oleh penyuluh perikanan PNS maka digunakan uji Kruskal-wallis untuk membandingkan dua populasi atau lebih yang saling bebas.

\section{Hipotesis:}

H0 : sebaran $\mathrm{k}$ populasi identik/sama.

H1 : minimal terdapat dua populasi yang sama.

Statistik uji Kruskal Wallis

$$
\begin{aligned}
& H= \frac{\mathcal{L}}{N(N+1)} \sum_{i=1}^{k} \frac{1}{n_{i}}\left[R_{i}-\frac{n_{i}(N+1)}{2}\right]^{2} \\
& \text { Ri } \quad=\text { Jumlah peringkat contoh ke }-\mathrm{i} . \\
& \mathrm{ni} \quad=\text { jumlah sampel ke-i } \\
& \mathrm{N} \quad=\text { jumlah total sampel }
\end{aligned}
$$

Jika terdapat ties (peringkat yang sama) antar dua atau lebih sampel maka setiap sampel diberi bobot rata-rata peringkat dari setiap ties. Statistik uji dikoreksi menjadi:

$$
H=\frac{\left[\frac{\mathcal{D}}{N(N+1)} \sum_{i=1}^{k} \frac{R_{i}{ }^{2}}{n_{i}}\right]^{2}-3(N+1)}{1-\left[\sum_{i=1}^{k}\left(t_{s}^{3}-t_{s}\right)\right]\left(N^{3}-N\right)}
$$

Membandingkan nilai $\mathrm{H}$ hitung dengan Tabel Khi-kuadrat dengan derajat bebas $\mathrm{k}-1$. Jika $\mathrm{H}$ hitung $>$ maka Tolak H0. Untuk melihat tingkat keeratan hu-bungan antara variabel bebas maka digunakan uji korelasi Rank Spearman pada taraf kepercayaan 0,05\% dengan rumus (Siegel, 1992). Uji Rank Spearman tersebut mempunyai rumus:

$$
r_{s}=1-\frac{6 * \sum_{i=1}^{n} d_{i}^{2}}{n\left(n^{2}-1\right)}
$$

Keterangan:

$$
\begin{array}{ll}
\mathrm{rs} & =\text { Koefisien korelasi spearman } \\
\mathrm{di} & =\text { Selisih antar jenjang } \\
\mathrm{n} & =\text { Banyaknya subyek }
\end{array}
$$

\section{Hasil dan Pembahasan}

\section{Profil Pembudidaya Ikan}

Profil pembudidaya ikan yang diamati terdiri atas umur, tingkat pendidikan formal, keikutsertaan 
Tabel 1 Sebaran Responden berdasarkan Umur, Tingkat Pendidikan Fomal, Kesertaan dalam Pelatihan dan Pengalaman Usaha Perikanan

\begin{tabular}{|c|c|c|c|c|c|c|c|c|}
\hline \multirow{3}{*}{ Kategori } & \multicolumn{6}{|c|}{ Wilayah } & \multirow{2}{*}{\multicolumn{2}{|c|}{ Total }} \\
\hline & \multicolumn{2}{|c|}{ Barat } & \multicolumn{2}{|c|}{ Tengah } & \multicolumn{2}{|c|}{ Timur } & & \\
\hline & $\mathrm{n}$ & $\%$ & $\mathrm{n}$ & $\%$ & $\mathrm{n}$ & $\%$ & $\mathrm{n}$ & $\%$ \\
\hline \multicolumn{9}{|l|}{ Umur } \\
\hline - Muda (umur 20-38 tahun) & 15 & 38,5 & 14 & 34,1 & 6 & 30,0 & 35 & 35,0 \\
\hline - Dewasa (umur 39-57 tahun) & 22 & 56,4 & 21 & 51,2 & 10 & 50,0 & 53 & 53,0 \\
\hline - Tua (umur 58-76 tahun) & 2 & 5,1 & 6 & 14,6 & 4 & 20,0 & 12 & 12,0 \\
\hline \multicolumn{9}{|l|}{ Tingkat Pendidikan Formal } \\
\hline - Rendah (Tidak Tamat/Tamat SD) & 20 & 51,3 & 17 & 41,5 & 12 & 60,0 & 49 & 49,0 \\
\hline - Sedang (SMP-SMA) & 19 & 48,7 & 23 & 56,1 & 6 & 30,0 & 48 & 48,0 \\
\hline - $\quad$ Tinggi (>SMA) & 0 & 0,0 & 1 & 2,4 & 2 & 10,0 & 3 & 3,0 \\
\hline \multicolumn{9}{|c|}{ Kesertaan dalam Pelatihan Usaha Perikanan } \\
\hline - Rendah ( tidak pernah) & 13 & 33,3 & 26 & 63,4 & 18 & 90,0 & 57 & 57,0 \\
\hline - Sedang (1-2 kegiatan) & 23 & 59,0 & 15 & 36,6 & 1 & 5,0 & 39 & 39,0 \\
\hline - Tinggi ( $>2$ kegiatan $)$ & 3 & 7,7 & 0 & 0,0 & 1 & 5,0 & 4 & 4,0 \\
\hline \multicolumn{9}{|l|}{ Pengalaman Usaha Perikanan } \\
\hline - Rendah (skor 1-12) & 28 & 71,8 & 30 & 73,2 & 12 & 60,0 & 70 & 70,0 \\
\hline - Sedang (skor 13-24) & 9 & 23,1 & 11 & 26,8 & 5 & 25,0 & 25 & 25,0 \\
\hline - $\quad$ Tinggi $($ skor $>24)$ & 2 & 5,1 & 0 & 00 & 3 & 15,0 & 5 & 5,0 \\
\hline
\end{tabular}

Sumber : Hasil analisis data (2013) dengan jumlah $n=100$ orang

dalam pelatihan dan pengalaman usaha perikanan. Hasil penelitian seperti pada Tabel 1.

Tabel 1 menunjukkan umur pembudidaya ikan mayoritas dewasa (39-57 tahun). Mayoritas tingkat pendidikan formal termasuk kategori rendah (tidak tamat SD/Tamat SD). Kesertaan dalam pelatihan dan pengalaman usaha perikanan termasuk kategori rendah. Perbedaan profil pembudidaya ikan an-tara wilayah barat, tengah dan timur dilakukan uji Kruskal Wallis Test dengan hasil seperti pada Tabel 2.

Tabel 2 menunjukkan bahwa umur, tingkat pendidikan dan pengalaman usaha perikanan pembudidaya ikan tidak terdapat perbedaan nyata secara statistik antar wilayah karena memiliki $p$-value lebih dari 0,05 , sedangkan keikutsertaan dalam pelatihan berbeda nyata antar wilayah karena memiliki $p$-value $=0,000$ lebih kecil dari 0,05 . Nilai mean rank keikutsertaan dalam pelatihan di wilayah barat lebih besar dibandingkan wilayah lainnya dikarenakan pembudidaya ikan di wilayah barat lebih sering mengikuti pelatihan perikanan dibandingkan wilayah lainnya. Hal ini karena di wilayah barat terdapat lokasi percontohan demfarm budidaya udang vanname dari Ditjen Perikanan Budidaya KKP. Selain itu di pembudidaya ikan di wilayah barat lebih sering mengikuti pelatihan yang diselenggarakan oleh Pusat Pelatihan Mandiri Kelautan dan Perikanan (P2MKP) "Kersa Mulya Bhakti" di Kecamatan Kapetakan, P2MKP "Pandawa Lima" di Kecamatan Panguragan selain pelatihan yang diselenggarakan oleh BKP5K Kabupaten Cirebon.

\section{Persepsi Pembudidaya Ikan terhadap Kompetensi Penyuluh Perikanan}

Persepsi pembudidaya ikan terhadap terhadap Kompetensi Kepribadian, Andragogik, Profesional dan Sosial Penyuluh Perikanan seperti pada Tabel 3. Tabel 3 menunjukkan persepsi pembudidaya ikan terhadap kompetensi kepribadian penyuluh perikanan termasuk dalam kategori tinggi (64\%), sedangkan terhadap kompetensi andragogik, profesional dan sosial termasuk kategori sedang dengan persentase berturut-turut sebesar $61 \%, 59 \%$ dan $60 \%$.

Untuk mengetahui perbedaan persepsi 
Tabel 2 Hasil Uji Kruskal Wallis Test terhadap Profil Pembudidaya Ikan

\begin{tabular}{lcccc}
\hline \multicolumn{1}{c}{ Variabel } & Barat & $\begin{array}{c}\text { Mean Rank } \\
\text { Tengah }\end{array}$ & Timur & $\begin{array}{c}\text { Kruskal Wallis Test } \\
\text { (p-value) }\end{array}$ \\
\hline Umur & 50,08 & 47,06 & 58,38 & 0,287 \\
Tingkat pendidikan formal & 48,63 & 54,01 & 46,95 & 0,502 \\
Keikutsertaan dalam pelatihan & 62,65 & 46,56 & 34,88 & 0,000 \\
Pengalaman usaha perikanan & 49,67 & 48,24 & 56,75 & 0,390 \\
\hline
\end{tabular}

Sumber : Hasil analisis data (2013) dengan jumlah $n=100$ orang

pembudidaya ikan terhadap kompetensi penyuluh perikanan yang bertugas di wilayah barat, tengah dan timur digunakan uji Kruskal-wallis (Tabel 4.) Tabel 4 menunjukkan semua kategori kompetensi penyuluh perikanan berbeda nyata antar wilayah (barat, tengah dan timur) karena memiliki $p$-value lebih kecil dari 0,05. Kompetensi kepribadian penyuluh perikanan di wilayah barat memiliki nilai mean rank lebih tinggi $(56,96)$ dibandingkan wilayah tengah dan timur, sedangkan kompetensi andragogik $(55,93)$, professional $(58,05)$ dan sosial $(59,77)$ penyuluh perikanan di wilayah tengah memiliki nilai mean rank lebih tinggi dibandingkan wilayah barat dan timur.

Kompetensi kepribadian penyuluh perikanan PNS yang bertugas di wilayah barat meliputi kecamatan Palimanan, Gunungjati dan Kapetakan lebih baik dibandingkan wilayah lainnya. Hal ini diduga berhubungan dengan intensitas kegiatan penyuluhan pada wilayah barat yang lebih tinggi dibandingkan wilayah lain. Penyuluh perikanan yang mempunyai kompetensi kepribadian yang baik dan sering berinteraksi dengan pembudidaya ikan terkait kegiatan percontohan dan pelatihan yang memberikan manfaat bagi pembudidaya ikan cenderung dipersepsikan baik oleh pembudidaya ikan.

Kompetensi andragogik penyuluh perikanan PNS yang bertugas di wilayah tengah meliputi kecamatan Beber, Greged, Talun, Tengahtani dan Dukupuntang dipersepsikan lebih baik oleh pembudidaya ikan dibandingkan wilayah lainnya. Hal ini diduga karena kompetensi penyuluh perikanan di wilayah tengah dalam hal pemahaman terhadap sasaran penyuluhan, perencanaan, pelaksanaan, evaluasi dan laporan penyuluhan, serta pengembangan sasaran untuk mengaktualisasikan berbagai kompetensi yang dimiliki lebih baik dibandingkan wilayah lain. Pemahaman sasaran penyuluhan perikanan sangat penting dikuasai oleh penyuluh perikanan unutk keberhasilan penyuluhan. Perwakilan pembudidaya ikan di wilayah tengah terlibat dalam penyusunan programa penyuluhan kecamatan di BP3K bersama-sama penyuluh perikanan yang membinanya. Atas dasar itu, pembudidaya ikan di wilayah tengah memberikan persepsi yang lebih tinggi pada kompetensi andragogik penyuluh perikanan dibandingkan pada wilayah barat dan timur.

Kompetensi profesional penyuluh perikanan PNS yang bertugas di wilayah tengah dipersepsikan lebih baik dibandingkan wilayah barat (kecamatan Palimanan, Gunungjati dan Kapetakan) dan timur (kecamatan Losari, Gebang dan Babakan). Hal ini diduga karena di wilayah tengah penyuluhan dilaksanakan oleh 4 orang penyuluh perikanan PNS, 2 orang diantaranya merupakan Penyuluh Perikanan pada jenjang Ahli Madya. Pembudidaya ikan memberikan persepsi lebih tinggi terhadap kemampuan penyuluh terkait teknis yang dihadapi di lapangan.

Kompetensi sosial para penyuluh perikanan PNS yang bertugas membina pembudidaya ikan di wilayah tengah lebih baik dibandingkan wilayah barat dan timur. Persepsi yang lebih baik pada kompetensi profesional diduga karena kemampuan komunikasi penyuluh perikanan yang bertugas di wilayah tengah lebih baik dibandingkan yang bertugas di wilayah barat dan timur.

\section{Hubungan antara Profil Pembudidaya Ikan, dan Layanan Penyuluhan dengan Persepsi Pembudidaya Ikan terhadap Kompetensi Penyuluh Perikanan}

Hubungan antara profil pembudidaya ikan 
Tabel 3 Persepsi Pembudidaya Ikan terhadap Kompetensi Kepribadian, Andragogik, Profesional dan Sosial Penyuluh Perikanan

\begin{tabular}{|c|c|c|c|c|c|c|c|c|}
\hline \multirow{3}{*}{ Kategori Kompetensi } & \multicolumn{8}{|c|}{ Wilayah } \\
\hline & \multicolumn{2}{|c|}{ Barat } & \multicolumn{2}{|c|}{ Tengah } & \multicolumn{2}{|c|}{ Timur } & \multicolumn{2}{|c|}{ Total } \\
\hline & $\mathbf{n}$ & $\%$ & $\mathbf{n}$ & $\%$ & $\mathbf{N}$ & $\%$ & $\mathbf{n}$ & $\%$ \\
\hline \multicolumn{9}{|l|}{ Kepribadian } \\
\hline Rendah (skor 10-20) & 0 & 0,0 & 0 & 0,0 & 0 & 0,0 & 0 & 0,0 \\
\hline Sedang (skor 21-30) & 9 & 23,1 & 14 & 34,1 & 13 & 65,0 & 36 & 36,0 \\
\hline Tinggi (skor 31-40) & 30 & 76,9 & 27 & 65,9 & 7 & 35,0 & 64 & 64,0 \\
\hline \multicolumn{9}{|l|}{ Andragogik } \\
\hline Rendah (skor $10-20$ ) & 0 & 0,0 & 0 & 0,0 & 0 & 0,0 & 0 & 0,0 \\
\hline Sedang (skor $21-30$ ) & 22 & 56,4 & 21 & 51,2 & 18 & 90,0 & 61 & 61,0 \\
\hline Tinggi (skor $31-40$ ) & 17 & 43,6 & 20 & 48,8 & 2 & 10,0 & 39 & 39,0 \\
\hline \multicolumn{9}{|l|}{ Profesional } \\
\hline Rendah (skor $10-18$ ) & 0 & 0,0 & 0 & 0,0 & 0 & 0,0 & 0 & 0,0 \\
\hline Sedang (skor 19 - 27) & 26 & 66,7 & 18 & 43,9 & 15 & 75,0 & 59 & 59,0 \\
\hline Tinggi (skor 28 - 36) & 13 & 33,3 & 23 & 56,1 & 5 & 25,0 & 41 & 41,0 \\
\hline \multicolumn{9}{|l|}{ Sosial } \\
\hline Rendah (skor 10 - 18) & 0 & 0,0 & 0 & 0,0 & 0 & 0,0 & 0 & 0,0 \\
\hline Sedang (skor 19-27) & 24 & 61,5 & 17 & 41,5 & 19 & 95,0 & 60 & 60,0 \\
\hline Tinggi (skor $28-36$ ) & 15 & 38,5 & 24 & 58,5 & 1 & 5,0 & 40 & 40,0 \\
\hline
\end{tabular}

Sumber : Hasil analisis data (2013) dengan jumlah $\mathrm{n}=100$ orang

dan layanan penyuluhan perikanan dengan persepsi pembudididaya ikan terhadap kompetensi penyuluh perikanan dianalisis dengan korelasi Spearman (Tabel 5). Tabel 5 menunjukkan pendidikan formal pembudidaya ikan mempunyai hubungan yang nyata dengan kompetensi andragogik penyuluh perikanan sebesar $-0,216$.

Pengalaman usaha pembudidaya ikan memiliki hubungan yang nyata pada persepsi pembudidaya ikan terhadap kompetensi profesional sebesar-0,235. Hal ini artinya semakin lama pengalaman usaha pembudidaya ikan maka semakin rendah persepsinya terhadap kompetensi profesional penyuluh perikanan pada taraf nyata 5\%. Pembudidaya ikan yang berpengalaman dalam usaha perikanan diduga memiliki harapan yang tinggi terhadap penguasaan materi penyuluhan oleh penyuluh perikanan.

\section{Hubungan antara Layanan Penyuluhan Perikanan dengan Persepsi Pembudidaya Ikan terhadap Kompetensi Penyuluh Perikanan}

Tabel 5 menunjukkan persepsi pembudidaya ikan terhadap layanan penyuluhan perikanan menentukan persepsinya terhadap kompetensi penyuluh perikanan Variabel yang memiliki hubungan antara layanan penyuluhan dengan persepsi pembudidaya ikan terhadap kompetensi penyuluh perikanan adalah: 1) intensitas penyuluhan per ikanan dengan kompetensi andragogik $\left(0,197^{*}\right)$, 2) materi penyuluhan perikanan dengan kompetensi profesional $(0,262 * *)$ dan kompetensi sosial $\left(0,245^{*}\right)$ dan 3) metode dan teknik penyuluhan perikanan dengan kompetensi kepribadian $(0,220 *)$, profesional $\left(0,308^{* *}\right)$ dan sosial $(0,442 * *)$ dari penyuluh perikanan.

Intensitas kegiatan penyuluhan mempunyai hubungan yang nyata dengan persepsi pembudidaya ikan terhadap kompetensi andragogik penyuluh perikanan dengan nilai nilai korelasi sebesar $0,197^{*}$. Hal ini menunjukkan semakin sering intensitas penyuluhan yang diikuti pembudidaya ikan maka semakin baik persepsinya terhadap kompetensi andragogik penyuluh perikanan pada taraf nyata $5 \%$. Pembudidaya ikan yang sering mengikuti kegiatan penyuluhan akan menilai baik persepsinya pada penyuluh perikanan karena menilai penyuluh perikanan memahami sasaran penyuluhan. 
Tabel 4 Hasil Uji Kruskal Wallis Test Persepsi Pembudidaya Ikan terhadap Kompetensi Penyuluh Perikanan

\begin{tabular}{|c|c|c|c|c|}
\hline \multirow[b]{2}{*}{ Variabel } & \multicolumn{3}{|c|}{ Mean Rank } & \multirow{2}{*}{$\begin{array}{c}\text { Kruskal Wallis Tes } \\
\text { (p-value) }\end{array}$} \\
\hline & Barat & Tengah & Timur & \\
\hline Kompetensi Kepribadian & 56,96 & 51,43 & 36,00 & 0,006 \\
\hline Kompetensi Andragogik & 52,79 & 55,39 & 36,00 & 0,011 \\
\hline Kompetensi Profesional & 46,67 & 58,05 & 42,50 & 0,032 \\
\hline Kompetensi Sosial & 49,73 & 59,77 & 33,00 & 0,000 \\
\hline
\end{tabular}

Sumber : Hasil analisis data (2013) dengan jumlah $n=100$ orang

Materi penyuluhan perikanan mempunyai hubungan yang nyata dengan persepsi pembudidaya ikan terhadap kompetensi kompetensi profesional dan kompetensi sosial penyuluh perikanan dengan nilai korelasi antara sebesar 0,262 dan 0,245. Hal ini menunjukan semakin baik materi penyuluhan yang disampaikan penyuluh perikanan maka semakin baik persepsi pembudidaya ikan terhadap kompetensi profesional dan sosial penyuluh perikanan pada taraf nyata 5\%. Materi penyuluhan terkait dengan kemampuan penyuluh dalam menguasai materi dan kemampuan penyuluh untuk berkomunikasi.

Metode dan teknik penyuluhan mempunyai hubungan yang nyata dengan persepsi pembudidaya ikan terhadap kompetensi kepribadian dengan nilai korelasi sebesar 0,220, sedangkan terhadap kompetensi profesional dan juga kompetensi sosial penyuluh perikanan mempunyai hubungan yang sangat nyata dengan nilai korelasi sebesar 0,308 dan 0,408. Hal ini menunjukan semakin baik metode penyuluhan maka semakin baik persepsi pembudidaya ikan terhadap kompetensi kepribadian, profesional dan sosial penyuluh perikanan. Penerapan dan pemilihan metode dan teknik penyuluhan perikanan yang tepat untuk pembudidaya ikan terkait pula dengan kemampuan penyuluh dalam menguasai materi penyuluhan dan kemampuan penyuluh untuk berkomunikasi.

\section{Kesimpulan}

Berdasarkan hasil penelitian disimpulkan bahwa Pembudidaya ikan mayoritas kategori usia dewasa (39-57 tahun) Tingkat pendidikan

Tabel 5 Hubungan antara Profil Pembudidaya Ikan dan Layanan Penyuluhan Perikanan dengan Persepsi Pembudidaya Ikan terhadap Kompetensi Penyuluh Perikanan

\begin{tabular}{llcccc}
\hline \multicolumn{1}{c}{ Noriabel } & \multicolumn{1}{c}{$\begin{array}{c}\text { Persepsi Pembudidaya ikan terhadap Kompetensi } \\
\text { Penyuluh Perikanan (Y) } \\
\text { No }\end{array}$} & $\begin{array}{c}\text { Kepribadian } \\
\text { (Y1) }\end{array}$ & $\begin{array}{c}\text { Andragogik } \\
\text { (Y2) }\end{array}$ & $\begin{array}{c}\text { Profesional } \\
\text { (Y3) }\end{array}$ & Sosial (Y4) \\
\hline 1. & Profil Pembudidaya Ikan (X1) & & & & \\
a. & Umur (X11) & $-0,031$ & $-0,034$ & 0,035 & 0,106 \\
b. & Tingkat Pendidikan Formal (X12) & 0,016 & $-0,216^{*}$ & 0,079 & $-0,020$ \\
c. & Kesertaan dalam pelatihan perikanan (X13) & 0,071 & 0,139 & $-0,092$ & $-0,036$ \\
d. & Pengalaman usaha perikanan (X14) & $-0,182$ & $-0,16$ & $-0,235^{*}$ & $-0,126$ \\
2. & Layanan Penyuluhan (X2) & & & & \\
a. & Intensitas penyuluhan (X21) & 0,099 & $0,197^{*}$ & 0,014 & 0,196 \\
b. & Materi penyuluhan (X22) & 0,108 & 0,166 & $0,262^{* *}$ & $0,245^{*}$ \\
c. & Metode dan teknik penyuluhan (X23) & $0,220^{*}$ & 0,162 & $0,308^{* *}$ & $0,442^{* *}$ \\
\hline
\end{tabular}

Sumber : Hasil analisis data (2013) dengan jumlah $\mathrm{n}=100$ orang

Keterangan : $\quad *$ signifikan pada taraf nyata $5 \%$

** signifikan pada taraf nyata $1 \%$ 
mayoritas termasuk kategori rendah (tidak tamat SD atau tamat SD). Keikutsertaan dalam pelatihan usaha dan pengalaman usaha para pembudidaya ikan termasuk dalam kategori rendah. Persepsi pembudidaya ikan terhadap kompetensi penyuluh perikanan di kawasan minapolitan Kabupaten Cirebon termasuk dalam kategori sedang, kecuali terhadap kompetensi kepribadian termasuk kategori tinggi. Persepsi terhadap kompetensi kepribadian sebesar 64\%, kompetensi andragogik sebesar $61 \%$, kompetensi profesional sebesar 59\% dan kompetensi sosial $60 \%$. Tingkat pendidikan formal dan juga pengalaman usaha para pembudidaya ikan mempengaruhi persepsi para pembudidaya ikan terhadap kompetensi penyuluh perikanan. Semakin sering intensitas penyuluhan maka semakin baik persepsinya terhadap kompetensi andragogik penyuluh perikanan. Semakin baik materi penyuluhan maka semakin baik persepsi pembudidaya ikan terhadap kompetensi profesional dan sosial penyuluh perikanan. Semakin baik penerapan metode dan teknik penyuluhan perikanan akan semakin baik persepsi pembudidaya ikan terhadap kompetensi kepribadian, profesional dan sosial penyuluh perikanan.

\section{Daftar Pustaka}

Asngari PS. 1984. Persepsi Direktur Penyuluhan Tingkat "Karesidenan" dan Kepala Penyuluh Pertanian terhadap Peranan dan Fungsi Lembaga Penyuluhan Pertanian di Negara Bagian Texas Amerika Serikat. Media Peternakan. 9(2). Fakultas Peternakan. Bogor (ID): Institut Pertanian Bogor.

Badan Ketahanan Pangan dan Penyuluhan Pertanian, Perikanan, dan Kehutanan Kabupaten Cirebon. 2013. Program Penyuluhan Pertanian, Perikanan, dan Kehutanan Tahun 2013.

De Vito JA. 1997. Komunikasi Antarmanusia; Kuliah Dasar. Alih Bahasa Agus Maulana. Jakarta (ID): Profesional Books.
Farida I. 2012. Persepsi Petani Terhadap Kompetensi Penyuluh Pertanian Lapangan di Kecamatan Pontang Kabupaten Serang. [tesis]. Bogor (ID): Institut Pertanian Bogor.

Gilley JG, SA Eggland. 1989. Principles of Human Resource Development. Toronto: AddisonWesley Pub. Co. Inc.

Kementerian Kelautan dan Perikanan. 2010. Permen KP No.12/MEN/2010 tentang Minapolitan. 2012. Permen KP No. 15/MEN/2012 tentang Rencana Strategis Kementerian Kelautan dan Perikanan.

Rogers EM, FF Shoemaker. 1971. Communication of Innovation: A Cross Cultural Approach. New York: The Free Press; A Division of Macmillan Publishing Co, Inc.

Rusmono M. 2008. Urgensi Sertifikasi dalam Pengembangan Kompetensi dan Profesionalisme Penyuluh Pertanian. Di dalam: Siti Amanah et al, editor. Pemberdayaan Manusia Pembangunan yang Bermartabat: Paradigma Baru Penyuluhan Pembangunan dan Urgensi Kelembagaan Sertifikasi. Prosiding Mayor Ilmu Penyuluhan Pembangunan. Bogor (ID): Sekolah Pascasarjana Institut Pertanian Bogor.

Scheaffer RI, W Mendenhall, Ott RL. 2006. Elementary Survey. Penerbit Duxbury.

Siegel S. 1992. Statistik Non Parametrik untuk Ilmuilmu Sosial. Jakarta (ID): PT. Gramedia Pustaka Utama.

Singarimbun M, S Effendi. 2008. Metoda Penelitian Survai. Jakarta (ID): LP3S.

Spencer LM, Spencer SM. 1993. Competence At Work: Models for Superior Performance. New York: John Wiley \& Sons, Inc.

Sobur A. 2003. Psikologi Umum. Bandung (ID): Penerbit Pustaka Setia. 